\title{
Når ulike avdelinger slås sammen til én stor
}

\author{
Opprettelsen av store sykehusavdelinger med ansvar for forskjellige \\ fagområder skaper mange problemer, også språklige. Hva skal slike \\ avdelinger hete? Navnevalget har konsekvenser for avdelingens trover- \\ dighet og legitimitet.
}

Da Oslo universitetssykehus ble dannet i januar 2009, sto man foran et omfattende arbeid med å etablere en helt ny organisasjonsstruktur. Det er nå bestemt at sykehuset fra 1.1. 2010 skal bestå av ti klinikker, hvorav Klinikk for spesialisert medisin og kirurgi skal ta seg av organtransplantasjon, nyremedisin, gastroenterologi, abdominalkirurgi, hematologi, hud- og veneriske sykdommer, revmatologi, deler av infeksjonsmedisin og klinisk immunologi (1). Hudog veneriske sykdommer, revmatologi, infeksjonsmedisin og klinisk immunologi blir samlet i én av fem avdelinger under klinikkledelsen (2).

Disse fagområdene har til nå vært fordelt på to avdelinger (Hudavdelingen og Revmatologisk avdeling) og en seksjon under Medisinsk avdeling (Seksjon for klinisk immunologi og infeksjonssykdommer) på Rikshospitalet (3). Sammenslåingen er kontroversiell, ikke minst ved Hudavdelingen, og stemningen ble ikke bedre da vedtaket om navnet på den nye avdelingen ble kjent: Avdeling for revmatologi, hud- og infeksjonssykdommer.

\section{Hva er galt med navnet?}

Det er mye som er galt med dette navnet. For det første er skrivemåten ikke i samsvar med gjeldende rettskrivningsregler. Når «hudsykdommer» og «infeksjonssykdommer» trekkes sammen til «hud- og infeksjonssykdommer», er «hud- og infeksjonssykdommer» ett element på linje med «revmatologi». Navnet må i så fall skrives slik: Avdeling for revmatologi og hud- og infeksjonssykdommer.

For det andre er det uheldig å trekke de to sykdomsgruppene sammen på en slik måte; den ene henspeiler på organ (hud) og den andre på kausalitet (infeksjon). Dette er like galt som å skrive lever- og bakteriesykdommer. De to sykdomsgruppene har lite med hverandre å gjøre, bortsett fra at veneriske sykdommer er infeksiøse, og at infeksjoner kan affisere huden.

For det tredje vil det lille ordet «hud-» oppfattes som klemt og gjemt (og glemt) mellom de mye lengre og dermed «tyngre» ordene «revmatologi» og «infeksjonssykdommer» foran og bak. Dette gjenspeiler ikke den nåværende hudavdelings størrelse. Av de tre enhetene har Hudavdelingen desidert flest pasienter, både med og uten Olafia-klinikken for seksuelt overførte sykdommer, og er den eneste - eneste - sykehusavdeling innen sin spesialitet i hele Helse Sør-Øst (med 2,6 millioner innbyggere) - i motsetning til hva som er tilfelle for revmatologi og infeksjonssykdommer.

For det fjerde er hovedansvaret for infeksjonssykdommer tillagt en annen klinikk. Derfor er det kunstig at «infeksjonssykdommer» har fått så stor plass i navnet.

Av mindre betydning er at ett ord er basert på latin og er betegnelsen på et fagområde («revmatologi»), mens de øvrige er norske betegnelser på sykdomsgrupper. «Klinisk immunologi» er ofret, antakelig for at navnet ikke skal bli for langt.

\section{Andre løsninger må finnes}

Navnevalg vekker følelser og er vanskelig, men andre løsninger må finnes. Klinikkledelsen har diskutert mange alternativer og har lovet en ny evaluering av avdelingsnavnet (og avdelingsstrukturen) i løpet av 2010. En åpen diskusjon bør derfor hilses velkommen. Saken har betydning ikke bare for Oslo universitetssykehus.

Bare hud- og veneriske sykdommer og revmatologi er spesialiteter, mens infeksjonssykdommer er grenspesialitet under spesialiteten indremedisin. Fordi hovedansvaret for infeksjonssykdommer er lagt til en annen klinikk, bør «infeksjonssykdommer» likevel vike til fordel for «klinisk immunologi», som berører bl.a. immunsviktpasienter.

Jeg foreslår følgende navn: Avdeling for hudsykdommer, revmatologi og klinisk immunologi. Svakheten er blandingen av norsk og latin, og at veneriske sykdommer ikke er kommet med. Begge deler er til å leve med. Rekkefølgen begrunnes i to forhold: den nåværende Hudavdeling har flest pasienter, og ordet «revmatologi» bør knyttes nærmest mulig opp til «klinisk immunologi» både av språklige og faglige grunner.

\section{Navn kommuniserer}

Oslo universitetssykehus er ikke alene om å velge lange, kompliserte, ukorrekte og/ eller uheldige navn på deler av sin organisasjon. Det gjelder også flere andre sykehus og institusjoner. Medisinsk forening for intellektuell (psykisk) utviklingshemning og habilitering, Norsk forening for otorhinolaryngologi/hode- \& halskirurgi og Norsk forening for fysikalsk- og rehabiliteringsmedisin er eksempler fra Den norske legeforening $(4,5)$.

Felles for slike navn er at man prøver å uttrykke eller favne for mye. Mange vil hevde at dette også er tilfelle med den nye avdelingen ved Oslo universitetssykehus: avdelingen favner for mye og for mye ulikt. De språklige vanskene gjenspeiler en konstruert og vanskelig virkelighet.

Navnet på en stor avdeling ved landets største universitetssykehus bør signalisere høy kompetanse. Jeg er redd mange vil oppfatte navnet Avdeling for revmatologi, hudog infeksjonssykdommer som uttrykk for slurv, mangelfull kompetanse og lavt presisjonsnivå. Det er ikke slik den nye avdelingen bør fremstå.

\author{
Petter Gjersvik \\ petter.gjersvik@rikshospitalet.no \\ Det medisinske fakultet \\ Universitetet i Oslo \\ Boks 1072 Blindern \\ 0316 Oslo
}

Oppgitte interessekonflikter: Forfatteren er førsteamanuensis ved Universitetet i Oslo ved den kommende Avdeling for revmatologi, hudog infeksjonssykdommer som arbeidssted.

Litteratur

1. Organisasjonskart for Oslo universitetssykehus per august 2009. Oslo: Oslo universitetssykehus, 2009

2. Nyhetsbrev. Oslo universitetssykehus. Klinikk for spesialisert medisin og kirurgi. Nr. 5-071009. Oslo: Oslo universitetssykehus, 2009.

3. Rikshospitalet. www.rikshospitalet.no (24.10.2009).

4. Gjersvik P. Langt og klossete eller kortere og bedre? Tidsskr Nor Legeforen 2008; 128: 956

5. Gjersvik P. Norsk forening for røde- og brannbiler. Tidsskr Nor Legeforen 2009; 129: 2274.

Manuskriptet ble mottatt 28.10. 2009 og godkjent 12.11. 2009. Medisinsk redaktør Raida Ødegaard. 